\title{
Development of the fruit bodies of Gyromitra esculenta
}

\author{
RISTO JALKANEN and ESKO JALKANEN
}

\begin{abstract}
JALKANEN, R. \& JALKANEN, E. 1981: Development of the fruit bodies of Gyromitra esculenta. - Karstenia 21: 50-52.

The development of the fruit bodies of Gyromitra esculenta (Fr.) Pers. was observed in the field in Central Finland $\left(62^{\circ} 18^{\prime} \mathrm{N}, 26^{\circ} 15^{\prime} \mathrm{E}\right)$. The first fruit bodies become visible when snow and ice are still present in the forest. The initial stages and very small fruit bodies were seen to develop during the previous year. The authors believe that there is a mycochrome in $G$. esculenta which reacts to the short daylengths in autumn and inhibits the development of the young fruit bodies, but which induces their growth in the spring, as the day is lengthening.
\end{abstract}

Risto Jalkanen, The Finnish Forest Research Institute, Rovaniemi Research Station, Eteläranta 55, SF-96300 Rovaniemi 30, Finland.

Esko Jalkanen, Mäkelä, SF-41400 Lievestuore, Finland.

The false morel (Gyromitra esculenta (Fr.) Pers.) produces fruit bodies only in the spring. The first fruit bodies (5-20 $\mathrm{mm}$ in diam.) can be seen by the naked eye at the end of April in South Finland (Jalkanen 1976), occasionally being visible as early as March on the southern coast (Roponen \& Kreula 1977). In South Finland the harvest period has ended by midJune. In North Finland fruit bodies can still be gathered in early July (Pohjola 1974).

Although they resemble Gyromitra esculenta and are often wrongly considered to be false morels, the species Gyromitra ambigua (Karst.) Harmaja, G. infula (Fr.) Quél. and Helvella lacunosa Fr. can be found only in the autumn.

Conflicting ideas have been proposed concerning the biology of G. esculenta. Most mycologists tend to believe that it is a mycorrhizal species like most of the cup fungi belonging to Basidiomycetes. However, these occur in the autumn and the occurrence of the fruit bodies in the spring is not consistent with the traditional view of the mycorrhizal fungi. It has been suggested that $G$. esculenta might be a saprophyte (Jalkanen 1975). It would then be easier to explain why its fruit bodies occur only in the spring.

The amount of the fruit bodies of $G$. esculenta can be increased by breaking the soil surface (Pohjola 1974, Jalkanen 1978). If the soil is disturbed in July, more fruit bodies are obtained in the next spring. In what manner does the stimulating effect of soil disturbance persist through the winter? Do the initial stages of the fruit bodies possibly develop in the autumn and survive over the winter?

\section{Field results}

Observations on the early occurrence of $G$. esculenta were made in connection with semi-cultivation studies in Lievestuore, Central Finland. The experiments took place in a natural Norway spruce (Picea abies L.) stand in a Vaccinium myrtillus forest site.

In May 1978, a fruit body was found inside ice in a trial pit (Fig. 1). Its volume was about one cubic centimetre. The fungus remained the same size for about one week, but increased its volume many times after the ice had melted.

In November 1974, when the ground was frozen to a considerable depth, a piece of soil (size $0.01 \mathrm{~m}^{3}$ ) was taken from a dense spruce forest. The piece was chipped off from the western side of trial pit no. 29 (see Jalkanen 1978:7), where false morels had occurred during the last two springs. It was taken into room temperature $\left(+18^{\circ} \mathrm{C}\right)$, and examined macroscopically after melting. No traces of the initial stages of fruit bodies of G. esculenta were found. The spring of 1975 turned out to be very poor for $G$. esculenta: not a single false morel was found in the spruce stand from which the sample was taken (see Jalkanen 1978:14). The summer and the autum of 1974 were warm but also rainy which evidently reduced the yield of $G$. esculenta (Jalkanen \& Jalkanen 1978).

In July 1979, a new semi-cultivation trial was established in the same area near the previous site. Its purpose was to find out how the yield of G. esculenta is affected by addition of organic matter to the soil. In some treatments the organic matter was covered by mineral soil taken from the treated area. This semi- 


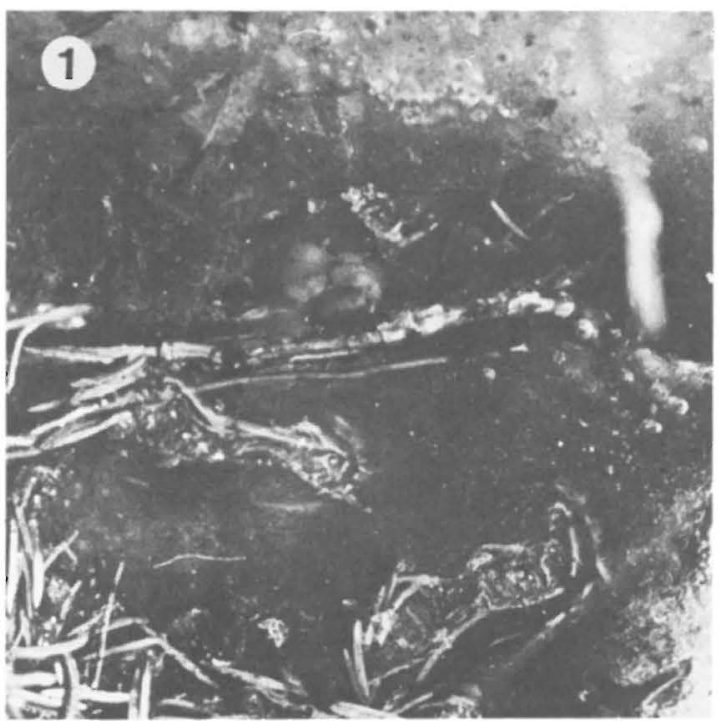

Fig. 1. A young fruit body of Gyromitra esculenta in early May inside the snowy ice. - Photo Jyrki Jalkanen 1978.

cultivation experiment is still in progress.

On May 1, 1980, small false morels were seen on the surface of the plots covered by mineral soil. There was still snow and ice in the forest. The maximum number of fruit bodies in a plot $\left(\right.$ size $1 \mathrm{~m}^{2}$ ) was 85 , and their height varied from 1 to $5 \mathrm{~mm}$. The stalks and cups were distinct. The fruit bodies remained the same size until mid-May. Part of them then began to grow and could be picked in early June. However, the majority of the fruit bodies withered away after early May. Many of the stunted fruit bodies were attached to clods of mineral soil loosened from the ground by the frost, which had thus broken their connection with the mycelium.

Since the summer of 1980 could be expected to be favourable for the decaying activity of $G$. esculenta (Jalkanen 1977), and the yield of 1981 was predicted to be a good one, it was decided that the trial plots should be checked until the coming of the snow.

In October 1980, a great number of small fungi nodules (height under $3 \mathrm{~mm}$ ) were found in the same plots. The nodes could be distinguished by the naked eye on the bare mineral soil (Fig. 2). Their maximum number was estimated at $1000-2000$ per $\mathrm{m}^{2}$. The largest of them resembled in form and colour the very young fruit bodies which were found at the same place in the spring, and which later developed into mature false morels. Many nodules already had both the cup and the stalk. In most cases the stalk was thickened at the base, this part being broader than the cup (breadth less than $1 \mathrm{~mm}$ ). No asci had yet developed in the nodes. The nodules were inoculated on malt agar in the laboratory, and the emerging mycelium proved to belong to G. esculenta. A control strain had been isolated the preceding spring, from a fruit body growing in one of these plots.

\section{Discussion}

The fruit bodies of G. esculenta can emerge as early as the time of the thaw (Jalkanen 1976) and during this study mycelial nodes were found in the ground in the autumn already. Evidently, all the fruit bodies found in late April have originated from the previous year. The summer months must therefore play a very important role in the decaying activity and in the formation of the initial stages of G. esculenta, thus determining how good a yield can be expected next spring. Probably many initials are always produced.

These observations support the theory that the daylength controls both the initiation of the primordia and the development of the fruit bodies. However, the growth rate of the fruit bodies depends on temperature. At the time of growth there is no lack of water. When the last fruit bodies have matured, the mycelium begins to store up energy for new fruit bodies. During this time the daylength is decreasing and this regulates the development of new fruit bodies. The check of short daylengths ceases in March. If the daylength is the only factor controlling the development of the fruit bodies, false morels could be obtained as early as October-November during favourable years by lengthening the day artifically. G. esculenta may possess some kind of pigment or compound which resembles the phytochrome of vascular plants, and which is able to react to the daylength.

According to Lukens (1965), phytochrome is present in Alternaria solani Sorauer, and by reacting to red light it initiates the sporulation of the fungus. In A. tomato (Cooke) G.F.Weber light of wavelength $310 \mathrm{~nm}$ is the most effective in inducing the formation of the conidiophores. The substance which reacted to light could be isolated from the fungal extract. Kudakai and Oda (1973) call this compound mycochrome. Sporulation can be inhibited by blue light, but NUV irradiation promotes it (Tan \& Epton 1974). Yellow light can also have an activating effect after a dark period (Ingold 1969).

Apparently, a minute quantity of light in March (one lux or less) is sufficient to induce formation of tiny fruit bodies in G. esculenta (see Inoue \& Furuya 1970). The discovery of a mycochrome in this species might make it possible to develop techniques for the cultivation of the fungus.

G. esculenta may also need the natural cold treatment apparently required by all northern plants or 

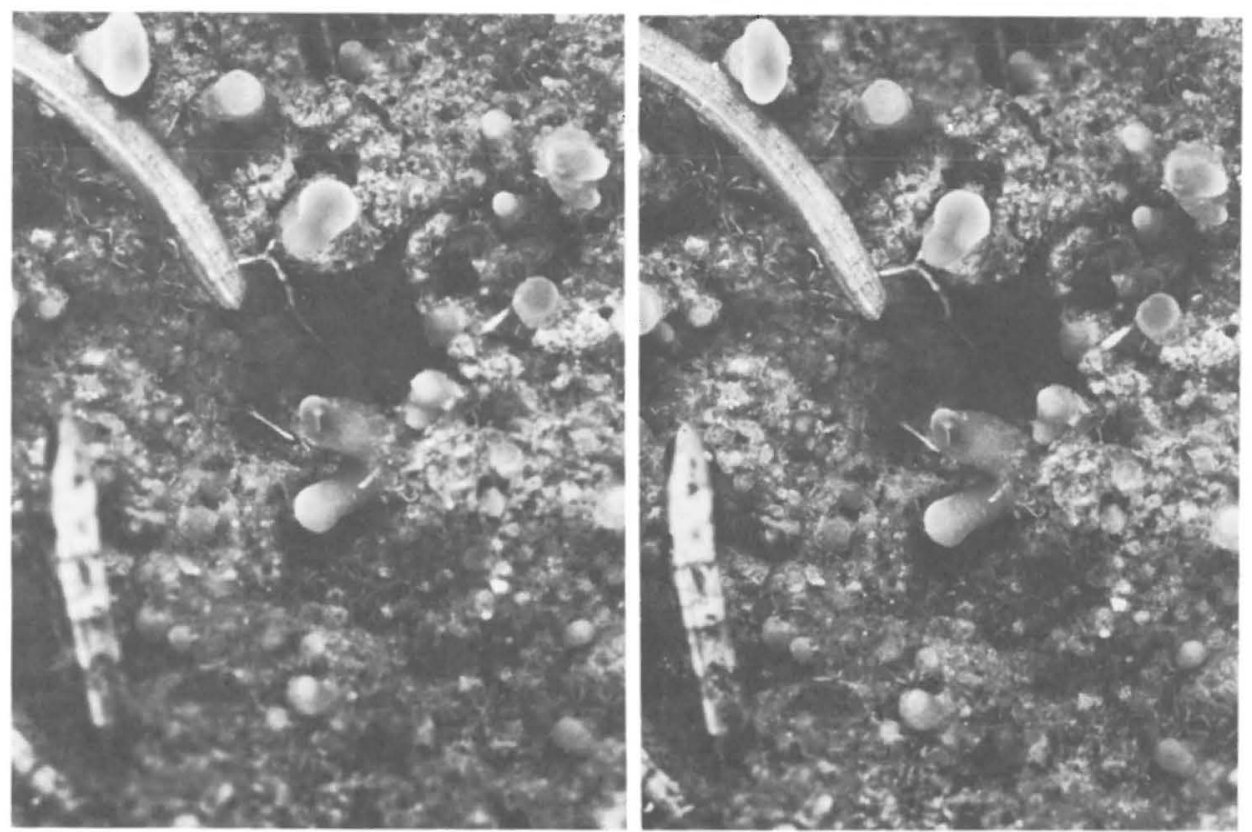

Fig. 2. Stereograph of frozen nodules of Gyromitra esculenta in early October. The spruce needle in the left upper corner is about $20 \mathrm{~mm}$. - Photo Olavi Huuri and Yliopiston kuvalaitos/Matti Ruotsalainen.

their seeds (see Raudaskoski et al. 1976). In the Basidiomycetes, in which the formation of the fruit body is simpler than in the Ascomycetes, the cold period is known to be important in Pleurotus ostreatus (Fr.) Kummer, at least (Zadrazil 1973).

Acknowledgements. The authors wish to thank Prof. Olavi Huuri, Mr. Jyrki Jalkanen, Mrs. Esteri Ohenoja, Lic.Phil., and Dr. Yrjö Norokorpi, who have read the manuscript and made valuable comments.

\section{References}

Ingold, C. 1969: Effect of blue and yellow light during the later developmental stages of Sphaerobolus. - Amer. J. Bot. 56: 759-766.

Inoue, Y. \& Furuya, M. 1970: Perithecial formation in Gelasinospora reticulispora 1. Effects of light at two different growth stages. - Devel. Growth Different.12:141-150.

Jalkanen, E. 1975: Luonnossa tapahtuvien korvasienen viljelykokeiden ongelmia. Sienitalousseminaari 7.-8.4.1975. - Jyväskylän Yliop. Biol. Lait. Tiedonantoja $1: 13-14$.

Jalkanen, R. 1976: Maanpinnan käsittelyn vaikutus korvasienen (Gyromitra esculenta (Fr. ex Pers.) itiöemien esiintymiseen mustikkatyypin kuusikossa Keski-Suomessa. - 58 pp. Manuscript, University of Helsinki, Department of Silviculture.
Jalkanen, R. 1977: Miten lisätään luontaista korvasienisatoa? - Sienilehti 4: 8-11.

- 1978: Maanpinnan rikkomisen vaikutus korvasienen satoisuuteen. (Summary: Effect of breaking the soil surface on the yield of Gyromitra esculenta). - Folia Forestalia 371: $1-18$.

Jalkanen, R. \& Jalkanen, E. 1978: Studies on the effects of soil surface treatments on crop of false morel (Gyromitra esculenta) in spruce forests. - Karstenia 18(suppl.): $56-57$.

Kudakai, T. \& Oda, Y. 1973: Blue and near ultraviolet reversible photoreaction with intracellular particulate fraction of the fungus, Alternaria tomato. - Plant Cell Physiol. (Tokyo) 14: 1107-1112.

Lukens, R. 1965: Reversal by red light of blue light inhibition of sporulation in Alternaria solani. - Phytopathology 55: 1032.

Pohjola, K. 1974: Studies on Gyromitra esculenta in Lapland. Paper presented at Arctic area Meeting 5.7.1974. -3 pp. Mimeogr.

Raudaskoski, M., Pohjola, K. \& Saarvanto, I. 1976: Effect of temperature and light on the mycelial growth of Gyromitra esculenta in pure culture. - Karstenia 16: $1-5$.

Roponen, I. \& Kreula, M. 1977: Korvasienen rihmaston kasvatuksesta. - Karjantuote 6-7: 4-7.

Tan, K. \& Epton, H. 1974: Ultraviolet-absorbing compounds associated with sporulation in Botrytis cinerea. - Trans. British Mycol. Soc. 62: 105-112.

Zadrazil, F. 1973: Pleurotus Florida FoVoSe - Porträt eines neuen Speisepilzes. - Thalacker Allgemeine Samenund Pflanzen-Offerte (Braunschweig) 8: 10. 